\author{
Andrzej Zaćmiński \\ https://orcid.org/0000-0002-8304-6375 \\ Uniwersytet Kazimierza Wielkiego w Bydgoszczy
}

\title{
Emigracja polska w Wielkiej Brytanii wobec wyborów do Sejmu PRL pierwszej kadencji z 26 października 1952 r.
}

\begin{abstract}
Abstrakt: Zmiany zachodzące w Polsce Ludowej po II wojnie światowej były bacznie obserwowane przez polskie uchodźstwo polityczne w Wielkiej Brytanii. Szczególną uwagę zwracano na sprawy polityczne. W artykule omówiono stosunek władz RP na obczyźnie oraz prasy emigracyjnej do wyborów do Sejmu PRL w 1952 r.: tzn. jak oceniano prawo wyborcze, Front Narodowy, jego program, kandydatów do sejmu, kampanię wyborczą oraz wyniki wyborów. W końcowej części tekstu skomentowano sukces, jaki rzekomo odniosło Ministerstwo Bezpieczeństwa Publicznego w tej części operacji „Cezary”, która dotyczyła dezinformacji środowisk emigracyjnych w zakresie propagandy wyborczej.
\end{abstract}

Słowa kluczowe: władze RP na obczyźnie, emigracja polska w Wielkiej Brytanii, Polska Ludowa, wybory do Sejmu PRL I kadencji, parlamentaryzm Polski Ludowej.

Abstract: The changes that took place in the Polish People's Republic after World War II were closely monitored by Polish political emigrants in Great Britain. Understandably, special attention was paid to political problems. The author discusses the attitude of the Polish government in exile and the Polish émigré press towards the elections to the People's Poland Sejm in 1952: i.e. their assessment of the electoral law, the National Front, its programme, candidates to the Sejm, the electoral campaign, and election results. In the closing part of the text, the author comments on the success allegedly achieved by the Ministry of Public Security in that part of the "Cezary" Operation which concerned disinformation of émigré community in the area of electoral propaganda.

Key w or d s: Polish authorities in exile, Polish emigration in Great Britain, Polish People's Republic, elections to the Sejm of the Polish People's Republic of the first term, parliamentarism of the Polish People's Republic. 
Wybory do Sejmu PRL pierwszej kadencji były nie tylko sprawą wewnętrzna Polski, ale również polskiej emigracji politycznej na Zachodzie, szczególnie w Wielkiej Brytanii. O ile w pierwszym przypadku wiele zagadnień zostało już opisanych w literaturze ${ }^{1}$, to stosunek emigracji do tego wydarzenia nie stanowił przedmiotu zainteresowań badaczy. Jest to ważny fragment w historii Polski, gdyż w Londynie działały władze RP na uchodźstwie, partie polityczne i organizacje społeczne, kulturalne, które z wielką uwaga śledziły wydarzenia oraz wszelkie procesy zachodzace w powojennej Polsce. Wynikało to nie tylko z ich politycznej roli, ale i z obowiązku, jaki na siebie przyjęła w 1945 r. emigracja. Miała ona bowiem walczyć o niepodległość Polski i być jej wolnym głosem na Zachodzie, informujacym opinię międzynarodową oraz środowiska polonijne o sytuacji w Polsce. W tym zakresie poczesne miejsce zajmowało ujawnianie i piętnowanie polityki reżimu komunistycznego, która określano mianem sowietyzacji Polski². Szczególną rolę poza wymienionymi instytucjami i organizacjami pełniła prasa, której bogactwo oraz różnorodność nie pozostały bez wpływu na kształt emigracyjnej opinii publicznej3.

Wybory do pierwszego Sejmu PR zorganizowano w okresie, kiedy funkcję premiera rządu na uchodźstwie pełnił gen. Roman Odzierzyński ${ }^{4}$. W exposé wygłoszonym 14 X 1950 r. na posiedzeniu Rady Narodowej Rzeczypospolitej Polskiej (RN RP) wiele miejsca poświęcił sprawom kraju. Przedstawiając program w tym zakresie, powiedział m.in.:

Im bardziej zaostrza się sytuacja polityczna na świecie, tym ostrożniej będziemy wypowiadać się na temat Kraju. Nie ustaniemy jednak w pracy nad demaskowaniem

\footnotetext{
${ }^{1}$ Stan badań na ten temat zob. A. Zaćmiński, Poezja agitacyjna w kampanii wyborczej do Sejmu PRL pierwszej kadencji z 26 października 1952 r. Tematyka-Obrazowanie-Polityka, „Dzieje Najnowsze” 2018, nr 2, s. 182. Po publikacji ukazała się książka M. Siedziako, Bez wyboru. Gtosowania do Sejmu PRL (1952-1989), Warszawa 2018, w której na s. 113-157 omówione zostały wybory do sejmu z $1952 \mathrm{r}$.

${ }^{2}$ Wśród prac poświęconych tej problematyce zob. Emigracja polska wobec sowietyzacji kraju, red. R. Sudziński, Toruń 2007; T. Wolsza, Rzqd RP na obczyźnie wobec wydarzeń w kraju 1945-1950, Warszawa 1998; idem, Opinie, oceny i propozycje „polskiego Londynu” w sprawie przystosowania społeczeństwa $w$ kraju do nowej rzeczywistości spoteczno-politycznej $i$ gospodarczej (przełom lat czterdziestych i pięćdziesiatych XX wieku), w: Polacy wobec PRL. Strategie przystosowawcze, red. G. Miernik, Kielce 2003, s. 37-55; także publikacje: Andrzeja Friszkego, Rafała Habielskiego, Pawła Machcewicza, Krzysztofa Tarki i in.

${ }^{3}$ W tym czasie w Wielkiej Brytanii ukazywało się ok. 280 tytułów prasowych i wydawnictw periodycznych, a gazeta codzienna „Dziennik Polski i Dziennik Żołnierza” wydawana była w nakładzie kilkunastu tysięcy egzemplarzy.

${ }^{4}$ W skład rządu, który zaprzysiężono 26 IX 1950 r., weszli: prezes Rady Ministrów i minister obrony narodowej R. Odzierzyński, minister spraw wewnętrznych Jerzy Hryniewski (właśc. Mikołaj Dolanowski), minister spraw zagranicznych Mieczysław Sokołowski, minister skarbu Stanisław Sopicki, minister dla spraw obywateli polskich na obczyźnie Zygmunt Rusinek. Kierowanie Ministerstwem Sprawiedliwości prezydent powierzył premierowi. 8 XII $1953 \mathrm{r}$. Odzierzyński podał się do dymisji.
} 
agentury, narzuconej narodowi polskiemu i sprawującej nad nim rządy terroru i bezprawia, ani też $\mathrm{w}$ obronie narodu przed obciążaniem go zarzutami za czyny zdziałane przez agenturę. [...]. Przemiany w Kraju winny być pilnie obserwowane. Musimy dokładnie zdawać sobie sprawę z nasilenia sowietyzacji Polski i wciagania jej bez reszty w układ komunistycznego systemu ${ }^{5}$.

To ostatnie zdanie jest szczególnie istotne, gdyż dotyczy nie tylko samego zjawiska, ale i jego dynamiki. Procesy te postrzegano jako implementację na grunt polski sowieckich wzorów i na bieżąco starano się je analizowaćc Szczególną uwagę zwracano na system polityczny i jego represyjny, policyjny charakter. Trudno zatem dziwić się, że duże zainteresowanie środowisk emigracyjnych wywołała uwertura do wyborów sejmowych, jaką było ogłoszenie projektu Konstytucji PRL. Stanowisko rządu w tej kwestii przedstawił premier Odzierzyński 26 IV 1952 r. na sesji RN RP7. Z kolei po jej uchwaleniu rząd RP na obczyźnie 23 lipca wydał oświadczenie, w którym stwierdzono:

Dnia 22 lipca 1952 roku sejm reżimowy w Warszawie uchwalił tak zwana nowa konstytucję znosząc tym samym resztki polskiego prawa państwowego, tolerowanego do tej pory przez uzurpatorów komunistycznych [...]. Wynika ona z bolszewickiej doktryny, głoszącej, że konstytucja jest tylko podsumowaniem osiagnięcia stopnia sowietyzacji [...]. Rząd Rzeczypospolitej składa uroczysty protest w imieniu całego Narodu Polskiego przeciwko temu nowemu aktowi przemocy, wtłaczającemu coraz bardziej Państwo Polskie w zupełną zależność od Związku Sowieckiego ${ }^{8}$.

Na temat projektu konstytucji i Konstytucji PRL wypowiedział się także prezydent RP na uchodźstwie August Zaleski, zaś jej szczegółowego omówienia dokonano na łamach prasy emigracyjnej ${ }^{9}$. Oprócz dziennikarzy głos zabrali również eksperci. Jednym z nich był Bohdan Podoski, prawnik, współtwórca Konstytucji kwietniowej i ordynacji wyborczej z 1935 r. Komentując to ważne wydarzenie ustrojowe dla Polaków, skonstatował, że data wejścia w życie konstytucji to kolejny dzień klęski w dziejach narodu polskiego ${ }^{10}$.

${ }^{5}$ Exposé premiera Odzierzyńskiego wygłoszone na Radzie Narodowej 6 października, „Lwów i Wilno" 1950, nr 17, s. 1.

${ }^{6}$ Znalazło to wyraz w wielu opracowaniach, analizach i artykułach prasowych. Od $1945 \mathrm{r}$. na łamach prasy emigracyjnej toczyła się również dyskusja na temat postaw, jakie Polacy powinni przyjąć wobec reżimu. Szczególnie interesujące publikacje oraz polemiki pojawiły się m.in. w „Wiadomości”.

${ }^{7}$ Instytut Polski i Muzeum im. gen. Sikorskiego w Londynie (dalej: IPMS), A.11E/1250a, „Diariusz RN RP” 1952, nr 1, Półroczne sprawozdanie prezesa Rady Ministrów gen. Odzierzyńskiego wygłoszone na Radzie Narodowej. Dokument opublikowano w: Wybór dokumentów do dziejów polskiego uchodźstwa niepodlegtościowego 1939-1991, oprac. i red. A. Suchcitz, L. Maik, W. Rojek, Londyn 1997, s. 193-214.

${ }^{8}$ Oświadczenie rzqdu RP w sprawie tzw. „Nowej Konstytucji”, „Orzeł Biały” 1952, nr 33, s. 1.

${ }^{9}$ A. Zaćmiński, Wydarzenia roku 1952 w Polsce w ocenie polskiego uchodźstwa politycznego $w$ Wielkiej Brytanii, w: Emigracja polska wobec sowietyzacji..., s. 393-397.

${ }^{10}$ B. Podoski, Sowiecka konstytucja dla okupowanej Polski, „Orzeł Biały” 1952, nr 15-16, s. 2. 
Przy omawianiu prawa konstytucyjnego w wypowiedziach polityków i prasie pojawiały się kilkuzdaniowe wzmianki oraz spostrzeżenia na temat prawa wyborczego. Wtedy też zasygnalizowano, że komuniści moga „wyniki wyborów do Sejmu PRL przygotować na długo przed ich przeprowadzeniem" ${ }^{11}$. Należy podkreślić, że we wszystkich publikacjach prasowych oraz dokumentach słowo „wybory” pisano w cudzysłowie. Zatem juz sam zapis sugerował, że nie chodzi tu o wybory w pełnym tego słowa znaczeniu, lecz tylko nazwę własną aktu, który w propagandzie komunistycznej aspirował do tego miana. Identyczna uwaga dotyczy pisowni innych nazw (np. sejmu), których zawartość semantyczna sama $\mathrm{w}$ sobie lub z desygnatem odbiegała od sfery praktyki.

Zainteresowanie wyborami w ścisłym tego słowa znaczeniu pojawiło się dopiero w kampanii wyborczej do Sejmu PRL, która zainaugurowało utworzenie 30 sierpnia Ogólnopolskiego Komitetu Wyborczego Frontu Narodowego $(\mathrm{FN})^{12}$. Wtedy też prasa emigracyjna i polska scena polityczna w Londynie na bieżąco komentowały jej przebieg. Ze względu na to, iż publicystyka, jak i wypowiedzi polityków były wielowątkowe oraz zawierały różnie rozłożone akcenty, w niniejszym tekście przedstawione zostały według kryterium rzeczowego. Oczywiście pierwszoplanowa rola należała do prasy, przede wszystkim do ukazującego się codziennie „Dziennika Polskiego i Dziennika Żołnierza”. Pozostałe tytuły prasy emigracyjnej, tzn. periodyki, przejawiały niewielkie zainteresowanie przebiegiem kampanii wyborczej i towarzyszacymi jej wydarzeniami. $Z$ reguły ograniczały się one do zamieszczenia dwóch lub trzech obszernych artykułów, z których jeden dotyczył wyborów, zaś ostatni ich podsumowania.

„Dziennik Polski i Dziennik Żołnierza” narrację o wyborach w Polsce rozpoczą 11 VIII 1952 r. Wtedy to opublikowano artykuł pt. Na podstawie sowieckiej ordynacji wyborczej $w$ dniu 26 października „wybory” $w$ Polsce. Podczas kampanii wyborczej nastapi wzmożenie terroru ${ }^{13}$. Poza ogólnymi informacjami tekst $\mathrm{w}$ całości poświęcono sejmowi wyłonionemu w sfałszowanych wyborach $1947 \mathrm{r}$. Na temat ordynacji wyborczej napisano tylko, że podobnie jak „konstytucja Bierutowa” oparta została na wzorze sowieckim, a jej projektodawcy nie napracowali się, gdyż niemal żywcem przepisali wiele artykułów. Jej kształt dostosowany został do sytuacji politycznej, a brak jawnej opozycji wynik wyborów czynił z góry wiadomym, tzn. „do sejmu

\footnotetext{
11 Bierut referentem „nowej konstytucji”, „Orzeł Biały” 1952, nr 21, s. 8.

12 Ta platforma wyborcza była atrapa, maska, kolejnym narzędziem transmisyjnym polityki PZPR. Oficjalnie prezentowano ją jako wyraz niezależnego komitetu wyborczego stanowiącego przejaw jedności narodowej. W rzeczywistości mimo „pluralistycznego składu” komitety FN podlegały podwójnemu nadzorowi PZPR. W trybie bezpośrednim czyniły to komitety PZPR właściwego szczebla, zaś pośrednio komitetami FN sterowały utworzone w nich tajne zespoły PZPR (odpowiedniki Podstawowych Organizacji Partyjnych PZPR).

13 „Dziennik Polski i Dziennik Żołnierza”, 11 VIII 1952, nr 191, s. 1.
} 
wejdą sami swoi, zawczasu wyznaczeni przez Politbiuro"14. Powyższą tezę redakcja „Dziennika...” przyjęła jako swoistego rodzaju aksjomat, uznajac, że nie jest on godny, aby poświęcać mu więcej uwagi. Nota bene, podobnie zachowali się politycy oraz redakcje innych pism emigracyjnych. Niemniej wszyscy udzielili odpowiedzi na pytania dotyczące celu komunistycznych wyborów, ich charakteru oraz sensu ich organizacji ${ }^{15}$. W najbardziej komunikatywny i przystępny sposób uczyniła to „Gazeta Niedzielna”. Autor artykułu, ukrywający się pod pseudonimem T.B., skonstatował, że przebieg wyborów i ich wynik zostały ustalone z góry, „gdyż nie ma kogo wybierać, bo nie ma konkurencyjnej listy. Urządzanie komedii wyborczej jest $\mathrm{w}$ tym systemie zbędne i najzupełniej niepotrzebne do sprawowania władzy [...]. Jednak organizuje się co pewien czas «wybory». Mało tego hasła wyborcze zabarwiane sa hasłami patriotycznymi i narodowymi. Wyrazem tego jest Front Narodowy"16. W tym kontekście autor publikacji pytał: po co wybory? Po co urządzają w Polsce jeszcze jedną tragiczną komedię wyborczą? Komu to i do czego jest potrzebne? Odpowiedź na powyższe pytania poprzedziła refleksja mówiąca, że komunistom w Polsce do sprawowania dalszych rządów terroru jest to całkowicie niepotrzebne. Również państwa zachodnie też już zdążyły się zorientować $\mathrm{w}$ sytuacji w Polsce na tyle, że owych wyborów nie wezmą za dobrą monetę. Zatem?

Jedyna odpowiedź tkwi w stwierdzeniu, że każde zło, każda zbrodnia czuje mimowolnie swą niższość wobec cnoty, wobec prawości i uczciwości i że musi jej składać hołd, w tym wypadku przez naśladowanie form uczciwości i wolności politycznej. Choć w tych formach nie maja już od dawna żadnej treści - trzeba ją zachować [...]. Zbrodniarz rzadko przyznaje się otwarcie do zbrodni, woli ją raczej ubierać w szaty cnoty, choć pod nimi każdy rozpozna jego właściwe oblicze ${ }^{17}$.

Wybory muszą się odbyć, gdyż „okupant nie może odpuścić żadnej okazji, by oszukać własne czy cudze sumienie. Więc społeczeństwo sterroryzowane, głodzone i tępione musi iść do urn wyborczych i "głosować z entuzjazmem» na swoich tyranów i okupantów"18. Według publicysty finał tych wyborów również nie będzie zaskoczeniem, gdyż prasa i radio komunistyczne zatrąbia w fanfary triumfu i zwycięstwa wyborczego nad konkurentami, których nie było. Ta przygnębiajacca, aczkolwiek trafna prognoza scenariusza wyborczego

${ }^{14}$ Ibidem. Również w artykule P.J., Sterroryzowane 99 procent, „Gazeta Niedzielna”, 16 XI 1952, nr 46, s. 3, postawiono pytanie: czy można nazwać sytuacje wyborami, w której w ogóle nie można wybierać?

15 Pytania te były zasadne, gdyż specyfika wyborów do sejmu w 1952 r. polegała na tym, że na jedno miejsce przypadał jeden kandydat.

${ }^{16}$ T.B., Dwa światy - i dwa rodzaje wyborów. 26 października nowy „Sejm” w Polsce i 4 listopada nowy prezydent $w$ Ameryce, „Gazeta Niedzielna”, 16 X 1952, nr 42, s. 1.

17 Ibidem.

18 Ibidem. 
uznana została przez autora „za tragedię całego świata, który zdradziwszy Polskę utracił i własny spokój i poczucie bezpieczeństwa"19.

Podobną ocenę i prognozę przedstawił Stanisław Klinga w obszernej i wszechstronnej analizie opublikowanej na łamach „Orła Białego” ${ }^{20}$. Według niego wyniki wyborów zostały już ustalone, za czym przemawiała tylko jedna lista wyborcza. Zaś głównym celem organizowanej elekcji miało być „tylko skłonienie możliwie największej liczby ludności do udziału w głosowaniu, zdobycie podrobionego wyrazu uznania od większości społeczeństwa" ${ }^{21}$. Analizując program $\mathrm{FN}$, zauważył, że nie ma w nim mowy o kolektywizacji wsi czy jej rozkułaczaniu. Nie nadużywano słowa „socjalizm”, co więcej, nawet nazwisko Józefa Stalina pojawiało się sporadycznie. Wybory w Polsce odbywały się pod hasłami „zjednoczenia narodowego”, a nie walki klasowej czy dyktatury proletariatu. W różnych materiałach przedwyborczych mówiono jedynie o Polakach, obywatelach, patriotach i ojczyźnie. Jego zdaniem taka konstrukcja programu miała na celu pozyskanie narodu polskiego za pomoca uczuć patriotycznych, głównie miłości do ojczyzny i wolności. FN operował zatem zwodniczymi hasłami, uciekając się do zakłamania na wielką skalę. Zygmunt Szempliński dostrzegł także, że data wyborów nie jest przypadkowa, gdyż odbędą się po zakończeniu zjazdu Wszechzwiązkowej Komunistycznej Partii (bolszewików) [WKP(b)] i na tydzień przed wyborami prezydenckimi w USA. W tym zestawieniu kalendarza wyborczego miała też wyrażać się zależność losów Polski od stosunków między dwiema największymi potęgami świata. Warto podkreślić, że emigracja czekała na wybór nowego prezydenta w USA, z którym wiąano duże nadzieje na zmianę polityki wobec sprawy polskiej22.

19 Ibidem. Jako kontrprzykład „drugi świat” przedstawione zostały wybory prezydenckie w USA.

${ }^{20}$ Stanisław Klinga (ps. Zygmunta Szemplińskiego) był ekonomista, sowietologiem, działaczem Polskiego Ruchu Wolnościowego „Niepodległość i Demokracja” (NiD) oraz dziennikarzem „Orła Białego”. W Polsce mieszkała jego rodzina, w tym córka Wanda Szemplińska-Stupnicka, znana pilotka szybowcowa, trzykrotna rekordzistka świata. Była pierwsza kobietą w Polsce i drugą na świecie, która zdobyła Diamentową Odznakę Szybowcową. Po zakończeniu kariery lotniczej pracowała jako profesor w Instytucie Podstawowych Problemów Techniki Polskiej Akademii Nauk.

${ }^{21}$ S. Klinga, „Wybory” $w$ Polsce, „Orzeł Biały” 1952, nr 40, s. 1.

${ }^{22} \mathrm{Na}$ ten temat pojawiło się kilka interesujących publikacji, wśród których na uwagę zasługuje artykuł Aleksandra Bregmana, pt. Czy rzeczywiście jesteśmy za polityka wyzwolenia?, „Dziennik Polski i Dziennik Żołnierza”, 2 X 1952, nr 236. Wywołał on polemikę, w której głos zabrali m.in. Tadeusz Schaetzel oraz Jędrzej Giertych. Pierwszy z wymienionych zgodził się z tezami Bregmana, akcentując, że „Niepodobna bowiem przypuszczać, aby przełamanie rosnącego napięcia między komunizmem a drugą częścią świata mogło nastapić inaczej jak przez rozwiązanie totalne. W ramach tego rozwiązania musi się mieścić wyzwolenie państw Środkowej Europy, zarówno jak i narodów ujarzmianych przez bolszewików po zwycięstwie rewolucji październikowej; mieścić się musi całkowite uwolnienie świata od agresji komunistycznej, tak samo jak i od każdego innego wcielenia historycznej zaborczości rosyjskiej”. Listy do redakcji. Dwa głosy o jednym problemie, „Dziennik Polski i Dziennik Żołnierza”, 18 X 1952, nr 250, s. 2. Nieco inny pogląd zaprezentował Giertych. Uważał on, 
Pojawiajace się w prasie emigracyjnej publikacje na temat wyborów do Sejmu PRL, ich charakteru oraz wyników były zbieżne z opiniami władz RP na uchodźstwie. Dość precyzyjnie przedstawił je na konferencji prasowej minister spraw wewnętrznych rządu RP Jerzy Hryniewski. Oświadczył, że

tzw. „wybory” urządzane przez reżim 26 października poza nazwą nie mają nic wspólnego z podobnymi aktami odbywającymi się w całym świecie z Polską międzywojenną włącznie. W Polsce nie ma żadnych wyborów, bo pojęcie to dramatycznie i logicznie łączy się z możliwością dokonania wyboru, czyli trzeba mieć co najmniej dwa elementy, z których jednemu daje się pierwszeństwo przed drugim. Tego właśnie w wyborach reżimowych nie $\mathrm{ma}^{23}$.

Również prezydent RP Zaleski 25 października na otwarciu jesiennej sesji RN RP odniósł się do komunistycznej elekcji: „Parodia wyborów z jedna lista kandydatów, mająca być wyrazem woli narodu jest najlepszym dowodem tego, czym jest w rzeczywistości tzw. "ludowa demokracja»" ${ }^{24}$. Dlatego tė̇ „w tych warunkach - mówił - z podziwem patrzymy na naród Polski, który z ufnością w Boga czeka na lepsze jutro, przechowując w głębi swego serca przywiąanie do Wiary Ojców i do odwiecznych tradycji narodowych, pomimo że wroga propaganda stara się mu je wydrzeć wszelkimi sposobami, jakie ma do dyspozycji”. Zaleskiemu wtórował premier Odzierzyński, który w przeddzień wyborów do Sejmu PRL podkreślił, że Polacy w „Kraju będa zmuszeni wziąć udział w tak zwanych "wyborach»"25. Uznał mobilizację społeczeństwa w kampanii wyborczej pod hasłami FN oraz brzmienie samej ordynacji wyborczej za przejaw kopiowania rozwiąań sowieckich. Stwierdził, że większość społeczeństwa niekomunistycznego podporządkowana jest komunistom, ci zaś działają według dyrektyw Kominformu. Dalej zaś mówił: „Wiemy dobrze, że «wybory» w żadnym stopniu nie są aktem swobodnej woli

że głównym celem jest wyzwolenie Polski, a wszystkie inne cele muszą zejść na dalszy plan. Zatem jeżeli „możliwe będzie wyzwolenie Polski bez równoczesnego wyzwolenia krajów położonych na wschód do nas tego nie wiemy”, trzeba to wykorzystać. „Troszczenie się przede wszystkim o własne interesy nie jest rzeczą niemoralna, lecz jest prostym nakazem zdrowego rozsądku". Dalej napisał, że gorąco pragniemy ogólnej krucjaty antysowieckiej, ale nie naszą rzeczą jest ją montować, gdyż nie można podejmować inicjatyw, których wykonanie nie leży w naszej mocy. Jednocześnie ostrzegał, że ta upragniona krucjata może kryć w sobie niebezpieczeństwa dla Polski. Jeżeli zwieńczy się sukcesem obalenie komunizmu na Kremlu i wyzwolenie narodu rosyjskiego, to dla nas jest to pożądane, tak samo jak dla całej ludzkości. Jeżeli będzie miała cel ograniczony, wyzwolenie Ukrainy (względnie oderwanie jej od Rosji itp.) może mieć skutki zgoła dla nas niepomyślne. Zamiast zwrócić nam wolność, odda nas w więzy systemu, w którym hegemonia będzie należeć do Niemiec i „w którym wyzwolenie Niemców i Ukraińców opłacone będzie naszą skórą". Ibidem.

${ }^{23}$ Rzqd Polski a wybory, „Dziennik Polski i Dziennik Żołnierza”, 18 X 1952, nr 250, s. 1.

${ }^{24}$ IPMS, A.48.Z.III/24, Przemówienie prezydenta RP Augusta Zaleskiego na otwarciu jesiennej sesji IV Rady Narodowej RP, Biuletyn PAT z 25 X 1952 r.

${ }^{25}$ IPMS, A.11E/1250a, „Diariusz RN RP” 1952, nr 1, Półroczne sprawozdanie prezesa Rady Ministrów..., s. 204. 
naszego społeczeństwa do głosowania na listę kandydatów, na której ułożenie nie miało ono żadnego wpływu. Znane już są na Zachodzie komedie wyborcze Związku Sowieckiego, gdzie na jedną listę ułożoną przez władze partii głosuje niemal 100\% obywateli. Teraz w Polsce będzie powtórzona ta sama gra" 26 . W konsekwencji, jak podkreślił premier, ani rząd, emigracja, ani też społeczeństwo w kraju nie nadadzą tak zaaranżowanym wyborom żadnego znaczenia, a wybrany w ten sposób sejm trudno będzie uznać za reprezentację narodowa.

Ze względu na to, iż emigracja polska w Wielkiej Brytanii miała wyrobiona opinię na temat elekcji do komunistycznego parlamentu, większą uwagę skupiono na wybranych aspektach kampanii wyborczej oraz politycznych konsekwencjach wyborów. Te ostatnie stanowiły wielką niewiadoma, stąd w publikacjach, przede wszystkim „Dziennika...”, spekulowano na temat ewentualnych roszad personalnych w Biurze Politycznym i rządzie. Wieszczono koniec kariery Józefa Cyrankiewicza jako premiera, który na tym stanowisku przetrwał 5 lat i 9 miesięcy. Jako argument podano fakt, iż od utworzenia gabinetu w 1947 r. „wymieniono mu praktycznie cały skład rządu”, a nad jego głowa „zbierały się czarne chmury” ${ }^{27}$. W związku z możliwością realizacji takiego scenariusza zastanawiano się, kto będzie jego następca. Uznano, że największe szanse na objęcie urzędu premiera mają Edward Ochab oraz Aleksander Zawadzki. Za wymienionymi kandydatami przemawiały ich życiorysy. Obaj bowiem byli „starymi przedwojennymi komunistami” cieszacymi się poparciem Związku Sowieckiego, a w przeszłości „pełnili zaszczytna funkcję politruków"28.

Publicyści zastanawiali się nie tylko nad personalnymi konsekwencjami wyborów do sejmu, ale także możliwością wykorzystania kampanii wyborczej do walki z przeciwnikami politycznymi. Odwołując się do okresu poprzedzającego wybory do Sejmu Ustawodawczego w 1947 r., prognozowano, że „politycznym «gwoździem» propagandowym w reżimowej kampanii wyborczej będzie niewątpliwie, co najmniej jeden duży i pokazowy proces sądowy. Najprawdopodobniej ta "sądowa kampania" rozpocznie się jeszcze we wrześniu, a być może przeciagnie się na październik, poprzedzając bezpośrednio dzień głosowania”29. Do takich refleksji redakcje „Dziennika...” skłonił duży wybór kandydatów na potencjalne ofiary procesów pokazowych. W artykule przypomniano, że w więzieniach na rozprawy sądowe oczekiwało 4 ministrów z rządu Cyrankiewicza (Włodzimierz Lechowicz, Józef Putek, Władysław Gomułka i Marian Spychalski) oraz 5 wiceministrów (Józef Dubiel, Włodzimierz Lechowicz, Piotr Jaroszewicz, Kowalewski, Kochanowicz). Teoretycznie

${ }^{26}$ Ibidem, s. 205.

${ }_{27}$ Jedyny rezultat wyborów październikowych. Kres kariery Cyrankiewicza. Zawadzki lub Ochab premierem, „Dziennik Polski i Dziennik Żołnierza”, 12 VIII 1952, nr 192, s. 1.

${ }^{28}$ Ibidem.

${ }_{29} 9$ dygnitarz oczekuje $w$ więzieniu rozprawy. Proces pokazowy poprzedzi wybory. W która stronę uderzy Politbiuro, „Dziennik Polski i Dziennik Żołnierza”, 10 IX 1952, nr 217, s. 1. 
możliwy był też proces pokazowy Gomułki i Spychalskiego. Jednak według publicystów „Dziennika...” ten scenariusz miał znikome prawdopodobieństwo, „gdyż uderzenie w tak wielki dzwon” wymagało czasu na przygotowanie procesu $^{30}$. Nie wykluczono, że Polska Zjednoczona Partia Robotnicza (PZPR) starając się zmusić masy chłopskie do udziału w wyborach, wykorzysta przebywajacych w więzieniach od 1951 r. 4 byłych posłów Polskiego Stronnictwa Ludowego: Kazimierza Nadobnika, Tadeusza Nowaka, Franciszka Kamińskiego i Zygmunta Załęskiego ${ }^{31}$. Poza tym w więzieniu na rozprawy czekali niektórzy posłowie reżimowego Stronnictwa Ludowego (SL), jak były minister poczt i telegrafów i prezes Rady Naczelnej SL Józef Putek, Władysław Kowalik, Stanisław Wrona-Merski czy Franciszek Roch-Kowalski. Biorąc pod uwagę bogaty i różnorodny skład więźniów politycznych, rozważano też inny wariant, a mianowicie wytoczenie procesu członkom Armii Krajowej, płk. Janowi Mazurkiewiczowi (ps. Radosław) czy płk. Janowi Rzepeckiemu lub współoskarżonym w procesie gen. Stanisława Tatara, m.in. gen. Józefowi Kuropiesce. Dziennikarz wymieniając Kuropieskę, nie wiedział, że 25 VI 1952 r. Najwyższy Sąd Wojskowy na niejawnym posiedzeniu skazał go na kare śmierci. Jednak to nie kończyło sprawy, gdyż Kuropieska próbując ocalić swoje życie, zaczął mataczyć w sprawie przygotowywanej przeciwko Spychalskiemu. Jego rewelacje były na tyle ważne, że Jakub Berman do listu wysłanego do Bolesława Bieruta, będącego na XIX Zjeździe WKP(b), dołączył - jak napisał - „ostatni protokół Kuropieski i protokół pierwszej konfrontacji, po której mają nastapić dalsze" ${ }^{32}$.

Publicyści „Dziennika...” zastanawiali się również nad tym, czy władze PRL nie wykorzystaja kampanii wyborczej do walki z Kościołem katolickim. Zorganizowanie procesu pokazowego ukazującego jego „wrogie i destrukcyjne” oblicze nie stanowiło problemu, gdyż w tym celu komuniści mogli posłużyć się m.in. aresztowanym Kazimierzem Studentowiczem czy ks. Zygmuntem Kaczyńskim ${ }^{33}$. Nie wykluczono także, że do programu kampanii przedwyborczej wejdą nieco mniejsze $\mathrm{w}$ skali politycznej procesy, a mianowicie np. „zabójców radiowego politruka Stefana Martyki” ${ }^{44}$.

${ }^{30}$ Ibidem, s. 4.

${ }^{31} \mathrm{Na}$ temat ludowców zob. J. Wrona, Stalinowskie doświadczenia ludowców, w: Represje wobec wsi i ruchu ludowego (1944-1989), t. IV: Między apologia a negacja, red. nauk. J. Gmitruk, E. Leniart, Warszawa 2010, s. 83-96.

${ }^{32}$ Archiwum Akt Nowych, Kolekcja akt różnej proweniencji, I/192, List Bermana do Bieruta z 7 X 1952 r., s. 69.

339 dygnitarz oczekuje..., s. 1. Oczywiście można ich było wykorzystać, ale jako świadków, gdyż w tym czasie nie byli aresztowani: ks. Kaczyński odbywał karę 10 lat więzienia na mocy wyroku Wojskowego Sądu Rejonowego w Warszawie z 29 VIII 1951 r., zaś Studentowicza skazano w maju $1950 \mathrm{r}$. na karę 15 lat pozbawienia wolności.

349 dygnitarz oczekuje..., s. 4. Prognozowany scenariusz urzeczywistnił się. Proces miał miejsce we wrześniu i był szeroko relacjonowany przez prasę PRL. Wyrokiem z 22 września cztery osoby skazano na karę śmierci. 
W miarę rozwoju kampanii wyborczej w Polsce prasa emigracyjna coraz częściej formułowała wnioski, uznając, że głosowanie będzie zwykła formalnością pozbawioną wpływów na wynik wyborów, a kandydatów można już uważać za przyszłych „posłów”. Nie oznaczało to jednak, że przygotowania do wyborów traktowano instrumentalnie. Z uwaga śledzono ogłaszane w kraju listy kandydatów na posłów. Analizując zestawienie z 23 okręgów (na ogólna liczbę 67), zauważono, że zmniejszy się liczba posłów z reżimowego SL i dotkliwie stopnieje sejmowa reprezentacja Stronnictwa Demokratycznego oraz koncesjonowanej Polskiej Partii Socjalistycznej ${ }^{35}$. Dostrzeżono wzrost liczby kobiet oraz literatów. Komentujacc listę „warszawska”, napisano, że „tak jak w Rosji moskiewska - ma nie tylko charakter reprezentacyjny, lecz również wskazuje na hierarchię ważności dygnitarzy Politbiura: Bierut, Rokossowski i Berman" ${ }^{36}$. Na podstawie lektury list wyborczych uznano, że komitety wyborcze wprowadzają w błąd opinię publiczna, gdyż „przy nazwiskach wielu czołowych aktywistów kompartii figuruje skromny dopisek «działacz społeczny». Tym określeniem obdarzono nie tylko pierwszych sekretarzy wojewódzkich kompartii, a nawet niektórych członków politbiura, jak np. S. Matuszewskiego lub F. Mazura" ${ }^{37}$.

Innym elementem, który piętnowała emigracyjna publicystyka, było umieszczenie na listach wyborczych, poza Konstantym Rokossowskim, generałów oddelegowanych z Armii Radzieckiej do Wojska Polskiego (Bolesława Kieniewicza, Bronisława Półturzyckiego, Wsiewołoda Strażewskiego i Jana Rotkiewicza) $)^{38}$. Odnośnie zaś do głosowania w wojsku napisano: „Nie ulega wątpliwości jaki będzie wynik wyborów w koszarach, gdzie żołnierze będą głosowali na rozkaz". Taki scenariusz wynikał nie tylko z jednej listy wyborczej, ale również włączenia wojska w kampanię wyborczą której podporządkowane zostały nawet obchody dnia Wojska Polskiego.

Opisujac kampanię wyborcza, starano się eksponować towarzyszące jej mechanizmy i deformacje. Zadanie to nie należało do trudnych, gdyż w miarę nasilania się stalinowskiej propagandy wyborczej w Polsce publicyści emigracyjni mieli szeroki wybór tematów do wielu ciekawych artykułów i refleksji. Jednym z nich było włączenie do kampanii wyborczej dzieci. „Dziennik...” w artykule poświęconym tej problematyce zrelacjonował przebieg „narady przodujących nauczycieli” z całej Polski, która odbyła się w Warszawie ${ }^{39}$. W tekście przywołano słowa wiceprzewodniczącego Związku Nauczycielstwa

${ }^{35}$ Komuniści kandydujajako... działacze społeczni. Berman w „wielkiej trójce” kampanii tuż po Bierucie i Rokossowskim, „Dziennik Polski i Dziennik Żołnierza”, 1 X 1952, nr 235, s. 1, 4.

${ }^{36}$ Ibidem, s. 4.

${ }^{37}$ Ibidem.

${ }^{38}$ Oczyszczone ze zdradzieckich elementów wojsko Rokossowskiego też głosuje a generałowie rosyjscy kandyduja do „sejmu”, „Dziennik Polski i Dziennik Żołnierza”, 22 X 1952, nr 253, s. 1.

${ }^{39}$ Dzieci musza pisać przedwyborcze donosy. Wzmożony wyzysk z okazji wyborów dla ratowania planów gospodarczych, „Dziennik Polski i Dziennik Żołnierza”, 23 IX 1952, nr 228, s. 4. 
Polskiego, który zadeklarował, że 180 tys. nauczycieli stoi do dyspozycji komitetów wyborczych FN. Mieli oni pracować jako prelegenci, agitatorzy i popularyzować sylwetki kandydatów na posłów. Uwadze redakcji nie uszły też słowa Ochaba, który zwracając się do nauczycieli „jako czołowych żołnierzy frontu rewolucji kulturalnej”, nawoływał ich do czujności wobec wroga klasowego i agentów imperializmu, mówiąc, że „szkoła jest nie tylko placówką oświatowa, ale również posterunkiem walki politycznej” ${ }^{40}$. Podkreślono, że wskazania Ochaba nie poszły na marne, gdyż w jednej ze szkół dzieci w klasie III otrzymały pisemne zadanie na temat: „Jak rodzice przygotowują się do głosowania”. W komentarzu redakcyjnym napisano, że „wypracowanie to ma wszelkie cechy pospolitego donosu i zmusza rodziców do ostrożnego wypowiadania się wobec własnych dzieci"41.

W publikacjach emigracyjnych opisano także różne formy agitacji. Szczególną uwagę skupiono na tzw. agitacji domowej. W artykule pt. Jeden agitator na dziesięć rodzin. Sfora przedwyborczych szpiegów dodatkowa plagq społeczeństwa $w$ Kraju przywołano instrukcję Komitetu Centralnego (KC) PZPR mówiąca o agitatorach, których główna rola polegała na „zachęceniu” ludzi do głosowania ${ }^{42}$. Każdemu z nich przydzielono po 10-15 rodzin, którymi miał opiekować się w czasie kampanii wyborczej. W tym celu agitatorzy zostali zobligowani do poznania rodzin, odwiedzania ich w domach, organizowania krótkich pogadanek i dyskusji oraz dostarczania literatury wyborczej. Ich zadaniem było przekonanie „elementów chwiejnych”, tj. ludzi starszych nienależących do żadnych organizacji, rzemieślników, gospodynie domowe itp. do udziału w głosowaniu. Działając socjotechnicznie, agitatorzy mieli też zainteresować się drobnymi problemami, z którymi borykali się wyborcy, m.in. brakami w zaopatrzeniu lokalnych sklepów czy znieczulicą urzędnicza. Ta zasada przysłowiowego kija i marchewki przez redakcje „Dziennika...” podsumowana została następująco: „część z nich [agitatorów - A.Z.] staje się automatycznie szpiclami bezpieki i wszystkie nieostrożne wypowiedzi trafiaja do lokalnych kartotek UB”. Samą zaś agitację określono następująco: „W ten sposób kilka tysięcy agitatorów wyborczych staje się przez wiele tygodni dotkliwą plagą nękająca całe społeczeństwo. Po wysłuchaniu codziennych audycji przedwyborczych radiowęzłów w zakładach pracy, po odbyciu okolicznościowych masówek przedwyborczych i tzw. spotkań «z kandydatami», człowiek nie ma spokoju we własnym domu, gdyż nachodzi go tam natrętny agitator" ${ }^{43}$.

${ }^{40}$ Ibidem.

${ }^{41}$ Ibidem.

${ }^{42}$ „Dziennik Polski i Dziennik Żołnierza”, 15 X 1952, nr 247, s. 1, 4. Opis pracy agitatora zob. Czarodziejska góra komunizmu. Rozmowa z Jackiem Eukasiewiczem (13 lutego 1981), w: J. Trznadel, Hańba domowa, Warszawa 1996, s. 51-72.

${ }^{43}$ Jeden agitator na dziesięć rodzin. Sfora przedwyborczych szpiegów dodatkowa plaga społeczeństwa w Kraju, „Dziennik Polski i Dziennik Żołnierza”, 15 X 1952, nr 247, s. 4. 
Środowiska emigracyjne krytykowały także różne inicjatywy, deklaracje czy zobowiazzania produkcyjne pojawiające się w kampanii wyborczej. W przypadku tych ostatnich nie kwestionowano ich propagandowej roli, ale jednocześnie podkreślano, że jest to przejaw wzmożonego wyzysku pracowników, służący również ratowaniu „ "trzeszczących» planów gospodarczych” ${ }^{44}$. Dostrzeżono tu sprzeczność między polityką a praktyką państwa ludowego, które zmuszało robotników do dodatkowej pracy bez gratyfikacji finansowej za jej wykonanie ${ }^{45}$. Poza tym niepokój wzbudził charakter podejmowanych zobowiązań, które ośmieszano w sposób niezwykle rzeczowy i przekonujący. Nota bene, nie było to trudne, gdyż prasa reżimowa w Polsce codziennie dostarczała wiele przykładów trącajacych groteska. Odnosząc się do nich w „Dzienniku...”, zauważono, że „niektóre z nich muszą budzić żywy niepokój przyszłych nabywców artykułów przemysłowych. Oto np. Zakłady Odzieżowe im. Dr. Więckowskiego w Łodzi zobowiązały się wykonać dodatkowo 1200 ubrań i zaoszczędzić jednocześnie $800000 \mathrm{~m}$. nici”" ${ }^{46}$. W komentarzu napisano, że to zobowiązanie produkcyjne nie pozostanie bez skutku na jakość ubrań, które znajdą się w sklepach państwowych.

Relacjonując przebieg kampanii wyborczej, emigracyjni publicyści opisywali różnego rodzaju kongresy, spotkania, narady, które bez względu na swój charakter służyły manifestowaniu jedności, np. przeciw „knowaniom amerykańsko-hitlerowskim” i agitacji „frontowo-narodowej” 47 czy też gloryfikacji osiagnięć władzy komunistycznej ${ }^{48}$. Były to imprezy wpisujące się w stalinowski folklor wyborczy, którym często nadawano charakter widowisk. Głównymi atrakcjami oprócz wypowiedzi partyjnych luminarzy oraz kandydatów na posłów były chóry, muzycy, aktorzy, pokazy filmowe itd., co oznaczało włączenie (zmuszenie) ludzi kultury i sztuki do firmowania kampanii wyborczej i programu wyborczego FN.

Odrębnym zagadnieniem, które znalazło odzwierciedlenie na łamach prasy emigracyjnej, był Kościół katolicki w Polsce, katolicy oraz ich rola w wyborach. Pierwsza, ogólna wzmianka na ten temat pojawiła się w „Dzienniku...” miesiąc przed wyborami. Wtedy też wyeksponowano fakt mówiący o tym,

${ }_{44}$ Dzieci musza pisać przedwyborcze donosy..., s. 4.

${ }^{45}$ Spostrzeżenie to powtórzono w innym artykule, pisząc: „W tygodniu przedwyborczym ogłoszono również, że w wielu fabrykach i hutach robotnicy zaciagnęli «samorzutnie» tzw. warty wyborcze w celu podniesienia produkcji - zwykły wyzysk, polegający na bezpłatnej pracy w nadgodzinach”. By uniknać zetknięcia z wyborcami Bierut gtosuje o 6-tej rano. W ostatniej chwili zwerbowano reżimowych katolików, „Dziennik Polski i Dziennik Żołnierza", 27 X 1952, nr 257, s. 1.

${ }^{46}$ Dzieci musza pisać przedwyborcze donosy...

${ }^{47}$ Propagandowy Kongres Ziem Odzyskanych. Przedwyborcza demonstracja we Wroctawiu - czyli stachanowcy popieraja „front narodowy”, „Dziennik Polski i Dziennik Żołnierza”, 24 IX 1952, nr 229, s. 1.

${ }^{48}$ Zjazd inżynierów $w$ Warszawie radzi o drapaczu chmur i... wyborach, „Dziennik Polski i Dziennik Żołnierza”, 4 X 1952, nr 238, s. 1. 
że reżim komunistyczny do FN angażuje również duchownych skupionych w Głównej Komisji Księży, działającej przy Związku Bojowników o Wolność i Demokrację. Wymieniono nazwisko ks. Antoniego Lampartego oraz poinformowano o wystosowaniu przez Główną Komisję Księży listu do Bieruta, w którym zadeklarowano publiczne poparcie dla akcji wyborczej ${ }^{49}$. Publicysta „Gazety Niedzielnej” omawiając to zagadnienie, ubolewał, że do komitetów wyborczych FN włączono kapłanów. Uznał to za próbę wykorzystania przez PZPR uczuć religijnych: „Giętkość propagandowa komunizmu sprawia, że duchowieństwo katolickie wciagaja do akcji wyborczej wyznawcy Lenina, który twierdził, że religia jest opium dla ludzi, że jest trucizna zaciemniająca umysł" 50 . Publicysta motywów takiego działania dopatrywał się w przebiegłości komunistów, którzy wiedzieli, że Polacy sa patriotami oraz religijni.

Zainteresowanie stosunkiem Kościoła katolickiego do wyborów nasiliło się po ogłoszeniu komunikatu przez Komisję Główną Episkopatu Polski 19 IX 1952 r. oraz komentujących go publikacjach prasy krajowej. Zarówno „Orzeł Biały”, jak i „Dziennik...” w swoich publikacjach odwołały się do artykułu z „Tygodnika Powszechnego”, pt. Nic co polskie nie jest nam obce ${ }^{51}$. Ryszard Piestrzyński ${ }^{52}$ komentując wezwanie biskupów do wypełnienia obowiązków płynących z prawa wyborczego, stwierdził, że wynikało ono z głębokiego zatroskania o los kraju i było przejawem stłumienia w sobie prawdziwych i szczerych uczuć, jakimi należało się kierować w dniu wyborów ${ }^{53}$. Podkreślił, że demokracja ludowa to forma dyktatury proletariatu i nie można być utopistą i nie liczyć się z realną rzeczywistością społeczno-polityczną. Katolicy nie mogą stać na marginesie tej rzeczywistości. Istnieją takie sprawy, „gdzie ze względu na dobro Kościoła konieczna jest czynna postawa katolików [...]. Stanowisko episkopatu jest zrozumiałe jeśli się weźmie pod uwagę, że głosowanie w nadchodzących "wyborach» i tak będzie przymusowe" ${ }^{54}$.

Stanowisko episkopatu dotyczyło uczestnictwa w wyborach, ale była też grupa katolików, która problem swoich relacji z władzą komunistyczna postrzegała nie tylko w sposób doraźny, ale również perspektywiczny. Chodziło o Bolesława Piaseckiego i jego stronników (ze Stowarzyszenia „PAX”) opowiadających się za współpracą z FN. Przybliżenia emigracji ich poglądów oraz polemiki z nimi podją się Stefan Mękarski. W artykule pt. Front Narodowy narzędziem bolszewizacji odwołał się do ogólnopolskiej konferencji

\footnotetext{
${ }^{49}$ Dzieci musza pisać przedwyborcze donosy..., s. 4.

${ }^{50}$ T.B., op. cit., s. 1.

${ }^{51}$ Artykuł ukazał się w nr 38 z 21 IX 1952, s. 1.

${ }^{52}$ W II RP dziennikarz „Kuriera Poznańskiego”, poseł na sejm z ramienia Narodowej Demokracji; redaktor naczelny warszawskiego „Kuriera Porannego”, w latach 1944-1957 redaktor naczelny tygodnika „Orzeł Biały”, wiceprezes Związku Dziennikarzy RP na Uchodźstwie.

${ }^{53}$ R.P., Jeszcze o „wyborach”, „Orzeł Biały” 1952, nr 41, s. 1.

${ }^{54}$ Gdy gtosowanie będzie i tak przymusowe. Katolicy a wybory w Polsce. Charakterystyczny głos episkopatu, „Dziennik Polski i Dziennik Żołnierza”, 2 X 1952, nr 236, s. 1, 4.
} 
intelektualistów i działaczy katolickich zorganizowanej w Warszawie pod hasłem zjednoczenia się w „tzw. Froncie Narodowym”. Nawiązując do wygłoszonego tam przez Piaseckiego referatu ${ }^{55}$, autor publikacji zdezawuował przedstawione przez niego zalety i korzyści wynikające dla katolików z udziału w FN. Nota bene, do tego celu wykorzystał brak spójności w wypowiedzi Piaseckiego, który wymienił zalety współpracy, po czym z rozbrajająca szczerościa przyznał, „że o zakres realizacji postulatów światopoglądowych i kulturalnych nie można się z marksistami umówić - to jednak dowodził, że katolicyzm w Polsce mógłby i musiałby tylko stracić, gdyby we Froncie Narodowym nie uczestniczył" ${ }^{2}$. Podobnych niekonsekwencji i sprzeczności Mękarski przytoczył więcej i zadał retoryczne pytanie, czy „Piasecki przekonał zebranych na konferencji księży i «patriotów» i «nie patriotów», pisarzy, publicystów, wśród nich przedstawicieli «Tygodnika Powszechnego», "Znaku», przekonał masy katolickie do idei Frontu Narodowego". Odwołał się też do wypowiedzi rzecznika konferencji: „taktyka przeczekania burzy dziejowej po ośmiu latach nie jest wyrazem rozsądku, ale przejawem małoduszności”. Komentując te słowa, napisał: „A więc po ośmiu latach naród niezmiennie chce ... przeczekać i dlatego jest ... nierozsądny i małoduszny"57. W podsumowaniu swoich rozważań, jako przeciwnik pielęgnowania złudzeń związanych z FN, wnioskował, że urzędowa doktryna zakłada uczynienie $\mathrm{z}$ niego narzędzia budownictwa komunistycznego, z czego zdają sobie sprawę katolicy i tym należy tłumaczyć ich wzmożoną krytykę.

Omawiając stanowisko Kościoła katolickiego do wyborów, trzeba zwrócić uwagę na kwestię możliwości ich bojkotu. Wątek ten pojawił się w prasie emigracyjnej oraz wypowiedziach polityków. Wprawdzie nie budził on kontrowersji, niemniej jednak zabierający w tej sprawie głos różnie rozkładali akcenty. Na przykład w przywołanym artykule omawiającym stanowisko episkopatu redakcja „Dziennika...” informowała, że „obywatel chcąc nie chcąc i tak będzie musiał iść do urny wyborczej [...]. Powstrzymanie się więc od głosowania narazić może na represje, a w niczym nie wpłynie na wynik wyborów (komisje zawsze "poprawią» liczby). W dodatku wolny świat nie ma już dzisiaj żadnych wątpliwości, co do znaczenia tych "wyborów»"58.

Problem ten poruszył również prezes Rady Ministrów Odzierzyński 25 października na sesji RN. Ustosunkowując się do pojawiających się na emigracji pomysłów proklamowania bojkotu wyborów oraz udzielenia narodowi polskiemu wskazówek, jak powinien zachować się w obliczu wyborów, powiedział:

${ }^{55}$ B. Piasecki, Perspektywy rozwojowe FN. Referat wygłoszony na Ogólnopolskiej konferencji intelektualistów i działaczy katolickich, „Dziś i Jutro”, 21 IX 1952, nr 38, s. 1. Zob. też: ks. J. Czuj, Katolicy we Froncie Narodowym, „Dziś i Jutro”, 12 X 1952, nr 41, s. 1.

${ }^{56}$ S. Mękarski, „Front Narodowy” narzędziem bolszewizacji, „Dziennik Polski i Dziennik Żołnierza", 25 X 1952, nr 256, s. 2.

57 Ibidem.

${ }^{58}$ Gdy glosowanie będzie i tak przymusowe..., s. 4. 
W warunkach panujaccego terroru, w warunkach niesłychanej presji na obywatela i uzależnienia go bez reszty od administracji reżimowej - rząd RP uznał tego rodzaju sugestie jako całkowicie pozbawione poczucia odpowiedzialności. Zwłaszcza dotyczy to bojkotu wyborów, który mógłby ściągnać na szerokie rzesze naszych rodaków, wykonujących zalecenia Rządu RP, tragiczne w skutkach represje reżimu ${ }^{59}$.

Ocena premiera była ze wszech miar pragmatyczna, gdyż istota wyborów do sejmu według władz PRL sprowadzała się do 100\% frekwencji wyborczej, co $\mathrm{w}$ propagandzie stanowić miało koronny argument mówiacy o masowym poparciu społeczeństwa dla programu FN i jego kandydatów. Mylił się natomiast premier, mówiąc, że szerokie rzesze rodaków mogłyby wykonać zalecenie rządu RP na uchodźstwie. Metody działania PZPR, a przede wszystkim totalna propaganda i inwigilacja oraz terror ze strony policji politycznej wykluczały takie zachowanie. Premier przecenił również siłę oddziaływania władz RP w Londynie na społeczeństwo polskie oraz możliwość podporządkowania się Polaków w kraju decyzjom politycznym władz emigracyjnych. Niemniej dezaprobata Odzierzyńskiego dla bojkotu wyborów była słuszna. Jakie zatem zachowanie zalecał rząd RP rodakom w kraju? Otóż „sprowadzało się ono do jednego zdania: "róbcie, czego od was pod terrorem żądaja, aby się nie narazić bezcelowo»". Za taką postawą zdaniem premiera miał przemawiać fakt, iż rząd i opinia międzynarodowa „tej nowej próbie oszustwa nie nadaje żadnego prawno-państwowego znaczenia"60.

Postulat prezesa Rady Ministrów, aby Polacy zachowywali się zgodnie z nakazami władz PRL, został skrytykowany w czasie dyskusji. Uczynił to m.in. Mękarski z Ligi Niepodległości Polski. Zgadzając się ze stanowiskiem rządu w sprawie bojkotu wyborów, uznał, że wypowiedziana przez premiera formuła: „Róbcie, czego od was pod terrorem żądaja”, jest niewłaściwa i niewychowawcza ${ }^{61}$. Według niego to nieszczęśliwe sformułowanie usprawiedliwiało oportunistów i psychicznych kapitulantów oraz rozgrzeszało ich z bezczynności. Mówiąc o FN, Mękarski podkreślił, że w jego szeregach znajdują się tzw. katolicy reżimowi. Uznał to za przejaw dywersji, zaś sam FN za narzędzie bolszewizacji Polski, tzn. konsekwentnie postępującej w Polsce sowietyzacji i rusyfikacji we wszystkich dziedzinach życia ${ }^{62}$.

Z lektury prasy emigracyjnej i wypowiedzi polityków nie wynika, aby z niecierpliwością oczekiwano na wyniki wyborów. Niemniej poświęcono im kilka publikacji. Najwięcej zamieszczono w „Dzienniku...” Od 27 października

${ }^{59}$ IPMS, A.11E/1250a, „Diariusz RN RP” 1952, nr 1, Półroczne sprawozdanie prezesa RM..., s. 205.

${ }^{60}$ Ibidem.

${ }^{61}$ Ibidem, Diariusz Rady Narodowej RP 1952, nr 1.

${ }^{62}$ Ibidem. Wyraził też zadowolenie z działalności Instytutu Badania Zagadnień Krajowych. Placówka ta powstała w 1951 r. z inicjatywy ministra spraw krajowych Dolanowskiego. Była kierowana przez Edwarda Szczepanika i miała na celu gromadzenie materiałów na temat Polski oraz ich opracowywanie na potrzeby władz RP i międzynarodowej opinii publicznej. 
do 3 listopada ukazały się 4 teksty i 1 kreskówka. Pierwszy artykuł opublikowano następnego dnia po głosowaniu i nie dotyczył wyników, lecz był ironicznym, na co wskazywał już tytuł, opisem głosowania. Czytelników poinformowano, że Bierut i członkowie Biura Politycznego KC PZPR oddali swe głosy o godz. 6 rano, kiedy większość ludzi w stolicy pogrążona była w głębokim śnie. „Przypuszczać należy, że tak wczesne pojawienie się «głowy państwa» i jego najbliższych współpracowników w lokalach wyborczych było wynikiem ostrzeżenia bezpieki, która wolała nie narażać dygnitarzy reżimowych na zetknięcie się z większym środowiskiem ludzi i z «obawami entuzjazmu» mas". Odnośnie do głosowania podkreślono, że trwało ono 14 godzin, od 6 do 22, a reżimowe radio sygnalizowało liczny napływ wyborców do urn. Zinterpretowano to jako próbę uprzedzenia wysokiego wyniku wyborczego, „przez który komuniści w Polsce będą się starali wmówić krajowi i światu, iż masowy udział w głosowaniu jest dowodem poparcia dla dyktatury agentów sowieckich w Polsce" ${ }^{63}$. Zasygnalizowano też po raz kolejny, że komuniści grali na uczuciach religijnych narodu i udało im się skaptować „księży patriotów" oraz reżimowych katolików, którzy uczestniczyli w szeregu wieców przedwyborczych.

Reakcje i komentarze na ogłoszenie wyników wyborów w Polsce były niezwykle ironiczne i doskonale oddawały je już same tytuły prasowe: $99 \%{ }^{164}$, Przedstawienie komedii wyborczej zakończone. Bierut gorszy o $5 \%$ od Stalina ${ }^{65}$, W Piotrkowie tylko 99,9\%...66, Sterroryzowane 99 procent $^{67}$ czy Wskaźnik wolności w cyfrach wyborczych ${ }^{68}$. „Dziennik...” powołując się na media w PRL, publikował fragmentaryczne wyniki wyborów, ograniczając się do krótkich, aczkolwiek dobitnych wniosków. Pisząc np. o frekwencji, stwierdzono, że „reżim w Polsce nie osiagnął jeszcze tego szczytu doskonałości podczas niedzielnych "wyborów» do sejmu do jakiego doszła Rosja". Bardziej wnikliwe komentarze ukazały się w „Gazecie Niedzielnej”. Autor ukrywający się pod inicjałami P.J., powołując się na paryskie „Słowo Polskie”, zaznaczył, że trzeba pamiętać, że absencja w głosowaniu była bardzo niebezpieczna, zaś cyfry ogłoszone przez komunistów wskazuja, że frekwencja była prawdziwa. Mimo że w komunizmie wszystko jest zakłamane, do tych liczb nie powinno się przywiązywać prawie żadnej wagi.

Tym nie mniej jest charakterystyczne, że nie zdołano w Polsce jeszcze osiagnąć sowieckiego poziomu 99,99 procent głosów. Właściwie to nie wiadomo - pisał publicysta - dlaczego komunistom, jak zresztą i innym totalistom, zależy tak na wskazaniu

\footnotetext{
${ }^{63}$ By uniknać zetknięcia z wyborcami Bierut głosuje o godz. 6-tej rano..., s. 1.

${ }^{64}$ „Dziennik Polski i Dziennik Żołnierza”, 28 X 1952, nr 258, s. 1.

65 „Dziennik Polski i Dziennik Żołnierza”, 30 X 1952, nr 260, s. 1.

66 „Dziennik Polski i Dziennik Żołnierza”, 3 XI 1952, nr 263, s. 1.

67 „Gazeta Niedzielna”, 16 XI 1952, nr 46, s. 3.

68 „Gazeta Niedzielna”, 23 XI 1952, nr 47, s. 1.
} 
jedności, w która nawet sami nie wierza. Bo przecież trudno byłoby uzasadnić, że ta śmiesznie mała garstka opozycjonistów w ustroju sowieckim mogłaby być aż tak niebezpieczna, żeby przeciw niej trzymać uzbrojone po zęby i wiecznie węszące oddziały bezpieczeństwa ${ }^{69}$.

Najbardziej krytyczną analizę wyników wyborów przeprowadził Stanisław Stroński. Podając je, napisał:

najzabawniejsze, a raczej jedynie zabawne, w tym ponuro głupim oszustwie jest to, że nasłannicy moskiewscy w Polsce chełpią się tymi wynikami, zresztą nie własnego pomysłu, lecz także - jak wszystko - naśladowanymi [...]. Jakby nie rozumieli, że w takie 99,8 procent może uwierzyć tylko ktoś, kto by uwierzył także, gdyby urzędowo ogłoszono, że w Polsce jest np. 99,8 proc. dnia, a 0,2 proc nocy lub na odwrót ${ }^{70}$.

Zaznaczył, że nie ma człowieka rozsądnego na świecie, który by nie wiedział, że 99,8\% oznacza, iż głosując na jedną listę wyborcza, nie było wyboru i wyborów, zaś głosowanie nie miało żadnego znaczenia i „nikt nawet poważnie tych głosów nie liczy, co byłoby nudna stratą czasu”. Ogłoszone wyniki z góry zostały ustalone w opętanym mniemaniu, że im więcej, tym to lepiej wygląda. Uznał, że prostactwo tego oszustwa dorównuje jego bezmyślności, gdyż takie 99,8\% znaczy jedynie, że „w tym kraju nie ma wyborów, nie ma życia obywatelskiego, nie ma wolności człowieka ani społeczeństwa. Jeśli takie 99,8 procent coś znaczy to chyba tylko, że jest tam 99,8 procent niewoli, a wolności tyle, ile brakuje do 100 procent, czyli 0,2 procent"71.

Podobnie wyniki elekcji parlamentarnej w Polsce, aczkolwiek nie aż tak krytycznie, postrzegał ambasador Wielkiej Brytanii w Warszawie Francis Michie Shepherd, który uznał, że były one „parodia demokratycznych wyborów"72. Stwierdził, że nie pojawiła się żadna sposobność, aby dokonać wyboru, a w kabinach umieszczono prowizoryczne zasłony dla tych, którzy byli nierozsądni i nie posłuchali zaleceń $\mathrm{FN}$, aby nie skreślać nazwisk.

Kampanię wyborczą do Sejmu PRL prasa emigracyjna przedstawiała nie tylko w formie werbalnej, ale również wizualnej. Stosował to głównie „Dziennik...”, który zamieścił 8 karykatur. Oznacza to, że jedna przypadała na 9 numerów pisma. Tylko jedna z nich ilustrowała tekst związany z wyborami. Pozostałe zamieszczano bez związku z zawartością tematyczna publikowanych tekstów, aczkolwiek z reguły odnosiły się do tematyki wyborczej artykułu z poprzedniego numeru. Takie rozwiązanie powodowało, że problematyka związana z wyborami do Sejmu PRL, bez względu na formę,

69 P.J., op. cit., s. 3.

70 S. Stroński, Wskaźnik wolności w cyfrach wyborczych, „Gazeta Niedzielna”, 23 XI 1952, nr 47 , s. 1.

${ }^{71}$ Ibidem.

72 Raporty roczne Ambasady Brytyjskiej $w$ Warszawie 1945-1970, oprac. M. Nurek, Warszawa 2003, s. 155. Shepherd funkcje ambasadora w Polsce pełnił od 22 V 1952 do 7 V 1954 r. 
gościła w prawie co trzecim numerze dziennika. Karykatury i kreskówki, podobnie jak i artykuły, poza pojedynczymi przypadkami, zamieszczano na pierwszej stronie. Ich symbolika ikoniczna nie była skomplikowana, gdyż bardziej przypominały rysunki zaopatrzone komentarzem.

Po wyborach do Sejmu PRL politycy i prasa emigracyjna nadal śledzili wydarzenia w Polsce. Było to logiczne, gdyż czekano na polityczne konsekwencje parlamentarnej elekcji. Sporadycznie też odwoływano się do wyborów, instrumentalizujac ich znaczenie. Na zorganizowanej w Londynie 11 listopada akademii z okazji Święta Niepodległości Polski Edward Raczyński apelował, aby wszędzie, gdzie to możliwe, bronić praw i interesów kraju, gdyż rządząca nim dyktatura powołuje się na $99 \%$ poparcia ze strony społeczeństwa ${ }^{73}$. Również prasa emigracyjna informowała o nowej roli $\mathrm{FN}^{74}$. Skromnie zrelacjonowano obrady Sejmu PRL pierwszej kadencji, uwagę zaś skoncentrowano na składzie Rady Państwa i nowym rządzie, na czele którego staną Bierut ${ }^{75}$. Gabinet składał się z 8 wicepremierów i 34 ministrów. W porównaniu z poprzednim został powiększony o 2 wicepremierów i 3 ministrów ${ }^{76}$. W rządzie znalazło się też 11 członków Biura Politycznego. Uwadze publicystów nie uszła również amnestia, która szczegółowo opisano. Uznano, że była podyktowana faktem przepełnionych więzień ${ }^{77}$.

Pisząc o stosunku „polskiego Londynu” do wyborów do Sejmu PRL, nie można pominąć operacyjnej gry pod kryptonimem „Cezary”, która Ministerstwo Bezpieczeństwa Publicznego (MBP) prowadziło wobec środowisk

${ }^{73}$ Uroczysty obchód święta 11 listopada. Kraj liczy na nas, „Dziennik Polski i Dziennik Żołnierza", 12 XI 1952, nr 271, s. 3.

${ }^{74}$ PZPR zmieni statut na wzór sowiecki. „Front narodowy” stała organizacja dla zwiazania bezpartyjnych z reżimem, „Dziennik Polski i Dziennik Żołnierza”, XI 1952, nr 267, s. 1. 31 X 1952 r. na Plenum Ogólnopolskiego Komitetu Wyborczego Frontu Narodowego podjęto uchwalę „o utrwalaniu i rozwijaniu jedności narodu w walce o rozkwit Ojczyzny”. Wtedy też zalecono, aby wszystkie struktury nadal kontynuowały swoją działalność, ale już jako komitety FN. Utrwalajmy i rozwijajmy jedność narodu w walce o rozkwit Ojczyzny. Uchwała Ogólnopolskiego Komitetu Wyborczego Frontu Narodowego, „Trybuna Ludu”, 3 XI 1952, nr 306, s. 1. Działalnościa tej ogólnonarodowej instytucji zachwiały wydarzenia 1956 r., a szczególnie VIII Plenum KC PZPR (19-21 X 1956 r.). Jego konsekwencją było nadanie starej formie nowego oblicza. Efekt tych przeobrażeń stanowiło powołanie 26 XI $1956 \mathrm{r}$. „nowej maski” pod nazwą Front Jedności Narodu (FJN), która przeprowadziła wybory do sejmu w 1957 r. Jednak oficjalne, inauguracyjne posiedzenie plenarne Ogólnopolskiego Komitetu FJN odbyło się dopiero 4 I 1958 r.

75 Ustrój Polski dostosowany do sowieckiego wzoru. Bierut (kieszonkowy Stalin) nowym premierem. Zawadzki na czele Rady Państwa (najwyższego sowietu), „Dziennik Polski i Dziennik Żołnierza”, XI 1952, nr 279, s. 1.

${ }^{76}$ Na czele 8 wicepremierów $i 34$ ministrów. Bierut tė̇ grozi syjonistom zapowiada walkę z trockistowskim odchyleniem, „Dziennik Polski i Dziennik Żołnierza”, 24 XI 1952, nr 281, s. 1.

77 Wobec przepetnienia więzień w Polsce Radkiewicz udziela okolicznościowej amnestii. Nie skorzysta z niej większość więźniów politycznych, „Dziennik Polski i Dziennik Żołnierza”, 24 XI 1952, nr 281, s. 1. 
emigracyjnych $^{78}$. Wprawdzie w literaturze akcja ta została opisana, to jednak nie doceniono jej „wątku wyborczego”. Z kolei bezpieka w swojej ocenie uznała, że prowadzona przez nią dezinformacja w sprawie wyborów zakończyła się wielkim sukcesem, gdyż emigracja przyjęła podsuniętą jej interpretację.

Po aresztowaniu IV Zarządu Głównego Zrzeszenia Wolność i Niezawisłość (ZG WiN) funkcjonariusze MBP przez podstawionych agentów utworzyli fikcyjny V ZG i rozpoczęli grę operacyjna pod kryptonimem „Cezary”79. Jej celem w wymiarze wewnętrznym było rozpracowanie podziemia zbrojnego w kraju, zaś zewnętrznym - środowisk emigracyjnych, a przy ich udziale współpracujacych z nimi wywiadów amerykańskiego (CIA) i brytyjskiego (SIS). Ten drugi człon realizowano za pośrednictwem działaczy Rady Politycznej (Edwarda Sojki) ${ }^{80}$ oraz funkcjonującej od 1946 r. w Londynie Delegatury WiN za Granica „Dardanele”. O ile całość operacji, która przerwano w końcu 1952 r., zakończyła się dużym sukcesem komunistycznej bezpieki, to wątpliwości budzi jej część, która odnosiła się do dezinformacji środowisk emigracyjnych w kontekście propagandy wyborczej. W opracowaniu „Cezary” dominuje megalomania typowa dla służb specjalnych, wynikajaca z przeświadczenia, że przekazane uchodźstwu politycznemu instrukcje, zalecenia itp. dotyczace propagandy wyborczej zostały zrealizowane. Jakie zatem wytyczne wobec wyborów kontrolowany przez MPB ZG WiN powtórzył Delegaturze do wykonania przez emigrację? Na pierwszym miejscu wymieniono:

bezsensowność i szkodliwość (oczywiście z punktu widzenia „interesów podziemia”) prób przeszkodzenia powszechnemu udziałowi ludności w głosowaniu (,bojkot spowoduje represje bezpieki”), jak również prób oddawania nieważnych głosów (,bezpieka ma możność ustalenia, kto oddał nieważny głos"). Jednocześnie przekonywaliśmy „delegaturę", że dla podziemia najkorzystniej będzie, gdy oddane zostaną czyste, nieskreślone karty (wg ordynacji wyborczej oznaczało to ważny głos za listą Frontu Narodowego) i że kierownictwo WiN i komitet polityczny domaga się, by w tym kierunku poszła propaganda emigracyjnych ośrodków, a przede wszystkim „wolnych rozgłośni”, tj. Wolnej Europy, Głosu Ameryki, BBC i innych szczekaczek ${ }^{81}$.

${ }^{78}$ MBP prowadziło permanentne działania celem rozpracowania środowisk emigracyjnych. Były to głównie przedsięwzięcia o charakterze wywiadowczym. Zob. W. Bagieński, Wywiad cywilny Polski Ludowej w latach 1945-1961, t. II, Warszawa 2017.

${ }^{79}$ Zob. m.in.: Operacja „Cezary”- ubecka analiza „gry” $z$ WiN-em, oprac. W. Frazik, „Zeszyty Historyczne WiN-u” 2001, nr 15, s. 183-255. W spisie treści błędnie wydrukowano początkową stronę publikacji - 163; zob. inne teksty tego autora w „Zeszytach Historycznych WiN-u” 2001, nr 16 oraz 2004, nr 22; także A. Zaćmiński, Wspótpraca Delegatury Zrzeszenia WiN za granica „Dardanele” z Zawiazkiem Sztabu Gtównego, w: Ludzie. Idee. Wojny. Studia $z$ dziejów Europy Środkowowschodniej. Księga pamiatkowa z okazji 70. rocznicy urodzin profesora Włodzimierza Jastrzębskiego, Bydgoszcz 2009, s. 124-142.

${ }^{80} \mathrm{Na}$ temat tzw. afery Bergu zob. A. Friszke, Życie polityczne emigracji, Warszawa 1999, s. 147-155 oraz jej skutków: W. Bagieński, op. cit., s. 185-204.

${ }^{81}$ Operacja „Cezary”..., s. 243. 
Z przedstawionego cytatu wynika, że bezpieka postawiła sobie i Delegaturze ambitne zadania. Jednak najważniejsze pytanie brzmi: czy miały one charakter dezinformacji? Raczej nie, gdyż większość środowisk emigracyjnych, w tym decydenckich, posiadała ogólne, ale wystarczające rozeznanie sytuacji politycznej w Polsce. Od 1945 r. „polski Londyn” zdecydowanie i jednoznacznie wypowiadał się przeciwko działalności „oddziałów leśnych” (podziemia zbrojnego), zaś społeczeństwu zalecano, aby stosowało formy, które nie będa zagrażały jego biologicznemu przetrwaniu ${ }^{82}$. Dotyczyło to bojkotu wyborów, ich znaczenia politycznego, represji, sposobu głosowania itp. Z przedstawionych wypowiedzi polityków i analizy publicystyki poświęconej wyborom wynika, że kreatorzy emigracyjnej opinii publicznej doskonale znali komunistyczne mechanizmy sprawowania władzy. W tym kontekście, aczkolwiek z odmiennych powodów, stanowisko emigracji zgodne było z zaleceniami dezinformacyjnymi MBP.

Jeżeli chodzi o Delegaturę WiN za Granica, to jej członkowie nie mieli żadnego wpływu na politykę władz RP czy poglądy prezentowane przez poszczególne tytuły prasowe. Nota bene, w tym czasie na emigracji, pomijając szczegóły związane z jej rozbiciem, „rządziło wojsko”, a przysłowiowe karty rozdawał gen. Władysław Anders za pośrednictwem rządu RP i gen. Stanisława Kopańskiego nadzorującego wszystkie struktury wojskowe. Dla nich Delegatura była taktycznym partnerem ${ }^{83}$, zaś jej współpraca z politykami Rady Politycznej dotyczyła zadań wywiadowczych. Niełatwo zatem uznać za sukces m.in. następujący fragment, który znalazł się w opracowaniu „Cezary”:

przekonaliśmy delegaturę, a przez to wrogie antypolskie ośrodki dyspozycyjne, że wobec ogromnych trudności i braku szans na powodzenie bojkotu, wobec i tak z góry pewnego i „ustalonego” rezultatu wyborów należy zaniechać propagandy nawołującej do bojkotu, bo to jeszcze bardziej odsunie „społeczeństwo” od emigracji, której wygodnie jest siedzieć bezpiecznie za granicą i prowadzić nieodpowiedzialne wystapienia i narażać „najlepszy element narodu” na represje. Udowadnialiśmy, że najlepszym argumentem „naszej” propagandy będzie wykazywanie, że wybory „reżimowe” i tak nie mają żadnego znaczenia, bo nic nie zmienia, wobec czego nie ma, co przeciwko nim jawnie występować itp. (jakiś „argument” trzeba było wrogom dostarczyć, wybrany został najmniej szkodliwy $)^{84}$.

Trudno komentować ten opis, gdyż razi naiwnościa, aczkolwiek zgodny jest z bolszewickim myśleniem życzeniowym, w którym fikcja zastępowała rzeczywistość. Emigracja doskonale wiedziała, jaką politykę prowadzi reżim

${ }^{82}$ Uznano to za zagrożenie i bezsensowne narażanie i utratę biologicznej tkanki narodu, co permanentnie podkreślano - szczegóły zob. T. Wolsza, Rzqd RP na obczyźnie..., s. 77-90; A. Zaćmiński, Emigracja Polska w Wielkiej Brytanii wobec możliwości wybuchu III wojny światowej 1945-1954, Bydgoszcz 2003, s. 109-129 i n.

${ }^{83}$ Szerzej zob. A. Zaćmiński, Wspótpraca Delegatury Zrzeszenia WiN..., passim.

${ }^{84}$ Operacja „Cezary”..., s. 244. 
komunistyczny, jaki jest cel wyborów oraz to, że niczego one nie zmienia, a ich wynik nie ma żadnego znaczenia. Dziwnie zatem brzmi konkluzja w opracowaniu „Cezary”: „Inspiracja powiodła się całkowicie. Nasze nastawienia spowodowały chaos we wrogiej propagandzie, która pospiesznie zaczęła się przestawiać i zmieniła nawoływania do bojkotu, na przekonywanie, że wybory nic nie zmienia, rezygnując $\mathrm{w}$ zasadzie $\mathrm{z}$ propagandy za przekreślaniem kart wyborczych" ${ }^{85}$. Z analizy wypowiedzi władz RP, polityków, publicystyki prasowej nie wynika, aby w prezentowaniu stanowiska do wyborów do Sejmu PRL wystapił jakiś chaos, zmiana strategii propagandowej itp. ${ }^{86}$ Nic takiego nie miało miejsca. Emigracja od początku kampanii wyborczej zajęła jasne i jednolite stanowisko do wyborów i pozostała mu wierna. To że ścierały się różne poglądy czy koncepcje, wynikało z pluralizmu, a nie z ubeckiej dezinformacji. Tym bardziej że nie dotyczyły one kwestii zasadniczych, tj. oporu wobec wyborów czy ich bojkotu. Autorzy opracowania „Cezary” przecenili wpływ Delegatury WiN za Granica „Dardanele” na propagandę środowisk emigracyjnych, a także skuteczność oddziaływania tych ostatnich na kraj. W ogóle nie dostrzegli, że o postawach Polaków nie decydowała propaganda, lecz twardy i miękki terror, jaki reżim komunistyczny stosował na masowa skalę w kampanii wyborczej. To on wymusił totalna konformizacje postaw, a nie „nastawienia” dla Delegatury czy emigracyjna propaganda.

\section{Streszczenie}

Władze RP na uchodźstwie oraz emigracyjna opinia publiczna uznały, że kampania wyborcza i wybory do Sejmu PRL z 26 X 1952 r. były kopią wzorów sowieckich. Słowo „wybory” pisano w cudzysłowie, nazywano je farsa, komedia, zaaranżowaną parodia, informujac, że kandydaci do sejmu wybrani zostali jeszcze przed głosowaniem, na co społeczeństwo nie miało żadnego wpływu. Front Narodowy uznano za narzędzie bolszewizacji, zaś jego program - socjotechnicznym oszustwem, które odwoływało się do uczuć patriotycznych Polaków, ich miłości do ojczyzny i wolności. Ukazując niedemokratyczny (sowiecki) charakter kampanii wyborczej, krytykowano PAX i księży zaangażowanych w działalność FN. Poparto stanowisko Episkopatu Polski i nie nawoływano do bojkotu wyborów, uznając, że nie warto narażać się, kiedy wyniki są już ustalone, a poza tym w każdej chwili można je poprawić. Kwestionowano frekwencję wyborcza, ironizując, że reżim w Warszawie nie osiagną jeszcze rosyjskiego stanu doskonałości. Wybory uznano za tragedię narodowa, wyrażając opinię, że świat nie uwierzy w 99,8\% poparcia Polaków dla władzy komunistycznej.

${ }^{85}$ Ibidem.

${ }^{86}$ Odrębnym problemem, który należałoby zbadać, jest polityka informacyjna polskojęzycznych rozgłośni radiowych: Radia Wolna Europa, Głos Ameryki i BBC. Rzecz w tym, że nie znajdowały się one pod kontrolą władz RP. Trudno też oczekiwać, aby wpływ na ich propagandę posiadało UB via Delegatura. Wywiady państw zachodnich w ramach współpracy z WiN koncentrowały się na zdobywaniu informacji, a nie propagandzie. 


\section{Polish Emigration in Great Britain towards the Election to the Sejm of the Polish People's Republic of the First Term on 26 October 1952}

The Polish government in exile and the Polish émigré public opinion regarded the electoral campaign and election to the Sejm of the Polish People's Republic on 26 October 1952 as a copy of Soviet models. The word "elections" was written in quotation marks, and they were called farce, comedy, and arranged parody. The Polish émigrés in Britain informed that the candidates to the Sejm had been chosen before the elections, and the people had had no influence on their choice. The National Front was regarded as a tool of Bolshevism, while its programme - a social engineering fraud that appealed to patriotic feelings of Polish people, their love for their country and freedom. Revealing the undemocratic (Soviet) nature of the electoral campaign, they criticised the PAX Association and priests involved in the activity of the National Front. They supported the position of the Polish Episcopate and did not call for the elections boycott since it was not worthwhile when the results were already established, and they could be changed anytime. The émigré public opinion ironically questioned the result, saying that the regime in Warsaw did not reach the Russian state of excellence yet. The elections were considered a national tragedy, and the opinion was expressed that the world would not believe in 99.8 per cent of Poles supporting the communist authorities

\section{Bibliografia}

Bagieński W., Wywiad cywilny Polski Ludowej w latach 1945-1961, t. II, Warszawa 2017. Emigracja polska wobec sowietyzacji kraju, red. R. Sudziński, Torun 2007.

Friszke A., Życie polityczne emigracji, Warszawa 1999.

Operacja „Cezary”- ubecka analiza „gry” $z$ WiN-em, oprac. W. Frazik, „Zeszyty Historyczne WiN-u” 2001, nr 15, s. 183-255.

Trznadel J., Hańba domowa, Warszawa 1996.

Wolsza T., Rzad RP na obczyźnie wobec wydarzeń w kraju 1945-1950, Warszawa 1998.

Wrona J., Stalinowskie doświadczenia ludowców, w: Represje wobec wsi i ruchu ludowego (1944-1989), t. IV: Między apologia a negacja, red. nauk. J. Gmitruk, E. Leniart, Warszawa 2010, s. 83-96.

Zaćmiński A., Emigracja Polska w Wielkiej Brytanii wobec możliwości wybuchu III wojny światowej 1945-1954, Bydgoszcz 2003.

Zaćmiński A., Poezja agitacyjna w kampanii wyborczej do Sejmu RPR pierwszej kadencji z 26 października 1952 r. Tematyka - Obrazowanie - Polityka, „Dzieje Najnowsze” 2018, nr 2.

Zaćmiński A., Wspótpraca Delegatury Zrzeszenia WiN za granica „Dardanele” z Zawiazkiem Sztabu Gtównego, w: Ludzie. Idee. Wojny. Studia z dziejów Europy Środkowowschodniej. Księa pamiatkowa z okazji 70. rocznicy urodzin profesora Wtodzimierza Jastrzębskiego, Bydgoszcz 2009, s. 124-141.

Biog r a m: Andrzej Zaćmiński - dr hab. nauk humanistycznych w zakresie historii najnowszej, prof. uczelni, kierownik Katedry Historii Najnowszej i Stosunków Międzynarodowych na Wydziale Historycznym Uniwersytetu Kazimierza Wielkiego w Bydgoszczy. Autor prac z zakresu historii polskiej myśli zachodniej w XX w., emigracji polskiej w Wielkiej Brytanii oraz historii Polski po 1945 r. Od 2012 r. wraz z prof. Momčilem Pavloviciem, dyrektorem Instytutu za savremenu istoriju w Belgradzie, kieruje projektem badawczym „Polska i Jugosławia w XX wieku”. E-mail: azhism@ukw.edu.pl. 